\title{
49 強酸性電解水製造装置の用途開発
}

浅岡伸太, 石黑克之, 松本 隆（サクラ精機）

本報告で用いた強酸性電解水製造装置は，薬事法で 認可を受けた手指の洗浄・消毒用の装置として使用さ れている．塩化ナトリウム水溶液を電気分解して陽極 側加得られる, pH 2.6, ORP $1140 \mathrm{mV}$, 有効塩素 濃度 $50 \mathrm{ppm}$ の次亜鉛素酸を主殺菌因子とする溶液を 製造する装置である，現在手洗いに限らず，医療，農 業, 環境分野でその利用が広く検討されている，強酸 性電解水の食品分野への応用ということで, 生野菜の 消毒効果を検討したので報告する.

現在，生野菜の消毒には次亜鉛素酸ナトリウムが使 用されている，厚生省の大量調理施設衛生管理マニュ アルに, 野菜および果物を加熱せずに供する場合, 次 亜鉛素酸ナトリゥムの $200 \mathrm{mg} / \mathrm{l}$ の溶液に 5 分間, 浸 漬することとある．この消毒剤は食品分野で広く使用 されているが, 塩素の使用濃度が高いため，作業者， 環境に多くの問題点を抱えているとの報告もある.

強酸性電解水, 次亚鉛素酸ナトリウム溶液の主殺菌
因子である次亚鉛素酸は，pHによりその性状，活性 が大きく異なる，次严鉛素酸ナトリウム溶液はアルカ り側にあるため, 次亜鉛素酸の存在比率が低く, 強酸 性電解水は酸性側にあるため, 次亚鉛素酸の存在比率 が高い，したがって強酸性電解水は有效塩素濃度を低 く抑えることが可能であり，作業者，環境への影響屯 少なく，塩素使用量を減らすことが可能である.

本報告では強酸性電解水之有効塩素濃度, $\mathrm{pH}$ を同 一にした次亜鉛素酸ナトリウム溶液を用い，理化学的 安定性，有機物に上る影響，生野菜に対する消毒效果 を比較した。

また別に，隔膜を持つ本装置の特徽として陽極側に 次西鉛素酸を主体とした強酸性電解水, 陰極側にアル カリ性電解水を生成する. 現状このアルカリ性電解水 は廃童されていることが多く, アルカリ性電解水が病 院施設で洗浄液として利用可能であるか検討を行った ので，併せて報告する。

\section{0 保育器の消毒方法に関する検討}

佐竹惠美子，小松克子，古田 康，犬山征夫（北游道大附属病院材料部）, 菊地 仁, 千葉仁志 (北海道大附属病院検查部), 向島智昭 (ムトゥテクノス)

〔はじめに〕当院材料部では, 1988年 3 月より保育 器の中央管理を開始し, 清掃・消毒・点検を実施して きた. 促来, 保育器の消毒方法は, 細菌学的検查の下, 患児の院内感染を危惧し，ホルマリンガス殺菌中和装 置による消毒法を用いてきた，しかし，患児に対する ホルマリンガスのリスクを考えると，安全な消毒方法 とは言い切れない，そこで，ホルマリン残留ガス濃度 を測定した結果，基準以下になるには日数を要するこ とが明らかになり，消毒方法の見直しを図ったので報 告する.

〔方法〕産科病棟から返却された保育器の細菌学的 検查（ホルマリン消毒前後, 薬液消毒前後, 紫外線殺 菌前後および各種消毒方法の比較検討）およびホルマ リン残留ガス濃度測定.
〔結果〕

1. ホルマリンガスと愁液消毒（清拭法）間での消毒 效果に対する有意差はなく，いずれの方法に扔い ても消毒後には菌の検出はみられなかった。

2. 保育器内に残留するホルマリンガス潧度は, 安全 領域に達するまでに 3 日間を要し，その後の減少 比率は極端に低下することが確認できた。

3. 紫外線殺菌灯の併用は消毒効果を高めるが，プラ スチック部品の変性が起こることから, 加湿タン クなど細菌繁殖につながる部品のみの併用とした。 以上の結果から, 安全な保育器を提供するためには, 日常は楽液消毒で対饦し, 感染症発生時にはホルマリ ンガス消毒とすること．また，ホルマリンガス消毒時 には, 日数を考慮した上で, 予備台数の確保, 緊急時 の貸出体制の見直しなどの指針が明らかになった。 